\title{
Glucagon-like peptide-1 prevents beta cell glucolipotoxicity
}

\author{
J. Buteau ${ }^{1}$ W. El-Assaad ${ }^{1}$ - C. J. Rhodes ${ }^{2}$ L. Rosenberg ${ }^{3} \cdot$ E. Joly ${ }^{1}$ M. Prentki ${ }^{1}$ \\ ${ }^{1}$ Molecular Nutrition Unit, Departments of Nutrition and Biochemistry, University of Montreal, CR-CHUM, Pavillon de Sève, \\ Montreal, PQ, Canada \\ 2 Pacific Northwest Research Institute and Department of Pharmacology, University of Washington, Seattle, Washington, USA \\ ${ }^{3}$ Department of Surgery, McGill University and the Montreal General Hospital, Montreal, Quebec, Canada
}

\begin{abstract}
Aims/hypothesis. We have provided evidence that glucagon-like peptide-1, a potential therapeutic agent in the treatment of diabetes, activates phosphatidylinositol-3 kinase/protein kinase B signalling in the pancreatic beta cell. Since this pathway promotes cell survival in a variety of systems, we tested whether glucagon-like peptide- 1 protects beta cells against cell death induced by elevated glucose and/or non-esterified fatty acids.

Methods. Human islets and INS832/13 cells were cultured at glucose concentrations of 5 or $25 \mathrm{mmol} / \mathrm{l}$ in the presence or absence of palmitate. Apoptosis was evaluated by monitoring DNA fragmentation and chromatin condensation. Wild-type and protein kinase B mutants were overexpressed in INS832/13 cells using adenoviruses. Nuclear factor- $\kappa \mathrm{B}$ DNA binding was assayed by electrophoretic mobility shift assay. Results. In human pancreatic beta cells and INS832/13 cells, glucagon-like peptide-1 prevented beta cell apoptosis induced by elevated concentrations of (i) glucose (glucotoxicity), (ii) palmitate (lipotoxicity) and
\end{abstract}

(iii) both glucose and palmitate (glucolipotoxicity). Overexpression of a dominant-negative protein kinase B suppressed the anti-apoptotic action of glucagonlike peptide-1 in INS832/13 cells, whereas a constitutively active protein kinase B prevented beta cell apoptosis induced by elevated glucose and palmitate. Glucagon-like peptide-1 enhanced nuclear factor- $\kappa \mathrm{B}$ DNA binding activity and stimulated the expression of inhibitor of apoptosis protein-2 and $\mathrm{Bcl}-2$, two antiapoptotic genes under the control of nuclear factor$\kappa \mathrm{B}$. Inhibition of nuclear factor- $\kappa \mathrm{B}$ by BAY 11-7082 abolished the prevention of glucolipotoxicity by glucagon-like peptide-1.

Conclusions/interpretation. The results demonstrate a potent protective effect of glucagon-like peptide-1 on beta cell gluco-, lipo- and glucolipotoxicity. This effect is mediated via protein kinase B activation and possibly its downstream target nuclear factor- $\kappa \mathrm{B}$.

Keywords Apoptosis - Glucagon-like peptide-1 . Glucolipotoxicity $\cdot$ Nuclear factor- $\kappa \mathrm{B} \cdot$ Pancreatic beta cell $\cdot$ Protein kinase B
Received: 3 October 2003 / Accepted: 16 January 2004

Published online: 17 April 2004

(C) Springer-Verlag 2004

M. Prentki (๘)

Molecular Nutrition Unit,

Departments of Nutrition and Biochemistry,

University of Montreal, CR-CHUM, Pavillon de Sève, Y-4603,

1560 Sherbrooke Est, Montreal, PQ, H2L 4M1, Canada

E-mail: marc.prentki@umontreal.ca

Tel.: +1-514-8908000, Fax: +1-514-4127858

Abbreviations: DN, dominant-negative $\cdot$ EMSA, electrophoretic mobility shift assay · GFP, green fluorescent protein · GLP-1, glucagon-like peptide-1 - IAP, inhibitor of apoptosis protein $\cdot N F-\kappa B$, nuclear factor $-\kappa B$.

PI-3K, phosphatidylinositol-3 kinase $\cdot \mathrm{PKB}$, protein kinase B . PKC- $\zeta$, protein kinase $\mathrm{C}-\zeta \cdot$ TUNEL, TdT-mediated

dUTP-biotin nick end-labelling

\section{Introduction}

Calorigenic nutrients, in particular glucose and NEFA, are the principal regulators of pancreatic beta cell function $[1,2,3,4]$. Short-term exposure of the beta cell to elevated concentrations of glucose promotes insulin release and enhances insulin biosynthesis $[1,5]$. However, chronic hyperglycaemia causes beta cell dysfunction characterised by reduced insulin biosynthesis [6] and increased levels of apoptosis (glucotoxicity) $[7,8,9,10,11]$. Similarly, acute exposure to NEFA potentiates glucose-induced insulin secretion by beta cells [12], whereas prolonged exposure to high concentrations of NEFA triggers beta cell apoptosis (lipotoxicity) [13,14, 15, 16, 17]. A recent study showed that protein kinase $\mathrm{B}$ (PKB) activation can 
rescue MIN6 cells from oleate cytotoxicity [18]. We initially developed the concept of glucolipotoxicity, proposing that elevated glucose and NEFA could have synergistic deleterious effects on the beta cell $[2,3$, 19, 20]. Glucolipotoxicity might play an important role in the beta cell decompensation phase during the development of obesity-associated Type 2 diabetes, since the effect of post-prandial and subsequently persistent hyperglycaemia, added to the high levels of NEFA and triglycerides, could lead to beta cell apoptosis and impaired beta cell function $[3,4,20]$.

Glucagon-like peptide-1- (7-36) amide (GLP-1), a potent gluco-incretin hormone [21, 22, 23] secreted by the intestinal L-cells in response to fat meals and carbohydrates [24], is a potentially important drug in the treatment of Type 2 diabetes in view of its ability to improve insulin secretion in subjects with impaired glucose tolerance and Type 2 diabetes mellitus [25, 26]. Through its ability to stimulate insulin gene expression and proinsulin biosynthesis [27] GLP-1 is also an insulinotropic agent. In addition, it induces several immediate-early response genes and proto-oncogenes in beta cells that are implicated in cell growth and/or apoptosis control, e.g. c-fos, c-jun, junD and nur77 [28, 29]. GLP-1 increases the DNA binding activity and expression level of the beta-cell-specific transcription factor pancreatic and duodenal homeobox gene-1 (PDX-1) [30, 31], which is implicated in regulating expression of the insulin, GLUT2 and glucokinase genes, and in the regulation of beta cell differentiation $[32,33,34]$. GLP-1 mobilises intracellular $\mathrm{Ca}^{2+}[35,36]$ via cyclic AMP guanine nucleotide exchange factor 2 (Epac) [37], an effect that may contribute to the insulinotropic action of the peptide. Moreover, this gluco-incretin hormone increases islet mass in mouse pancreas in vivo $[31,38]$ and causes in vitro beta cell proliferation via transactivation of the epidermal growth factor receptor and subsequent activation of the phosphatidylinositol-3 kinase (PI-3K) and protein kinase $\mathrm{C}-\zeta(\mathrm{PKC}-\zeta)$ signalling pathway in beta-(INS-1)-cells [30, 39, 40]. Finally, GLP-1 has recently been shown to delay beta cell apoptosis in Zucker diabetic rats, an animal model of diabetes [38], as well as in streptozotocin-treated mice and cytokinetreated rat islets in vitro [41].

The aim of the present study was to investigate whether GLP-1 prevents beta cell glucolipotoxicity and, if so, gain insight into the mechanism of its antiapoptotic effect.

\section{Materials and methods}

Reagents. Human GLP-1 fragment 7-36 amide was obtained from Bachem (Torrance, Calif., USA). RPMI 1640 and the cell culture supplements, including FCS, were purchased from Gibco BRL (Burlington, Ont, Canada). Protein concentrations were determined using the Bio-Rad protein assay (Bio-Rad, Hercules, Calif., USA).
Human islet isolation and culture. Human islets were isolated from six organ donors at the Department of Surgery of the Montreal General Hospital (McGill University Health Center). Ethics approval was granted by the McGill University Health Center Ethics Committee. Donors were between 50 and 65 years old and none had a history of diabetes or metabolic disorder. Islets were separated from the surrounding exocrine tissue by enzymatic digestion as described in [20], and then cultured overnight in regular RPMI 1640 medium containing $10 \%$ FCS, $10 \mathrm{mmol} / \mathrm{l}$ HEPES, $2 \mathrm{mmol} / \mathrm{l} \mathrm{L}$-glutamine, $1 \mathrm{mmol} / \mathrm{l} \mathrm{so}-$ dium pyruvate, $100 \mathrm{IU} / \mathrm{ml}$ penicillin and $100 \mu \mathrm{g} / \mathrm{ml}$ streptomycin. This was done in a humidified $\left(5 \% \mathrm{CO}_{2}, 95 \%\right.$ air) atmosphere at $37{ }^{\circ} \mathrm{C}$. The next day, intact islets were either directly used and treated with the different substances to be tested or dispersed in single cells and small clusters of cells by trypsinisation, attached on poly-ornithine glass coverslips as previously described [39] and subsequently incubated under various experimental conditions. Apoptosis was studied by three different methods measuring chromatin condensation, DNA fragmentation and release of histone-associated mono- and oligonucleosomes according to the protocols described below.

Cell culture and incubation. INS832/13 cells [42] (passages 46-70) were grown in monolayer cultures as described previously [43]. This was done in a humidified $\left(5 \% \mathrm{CO}_{2}, 95 \%\right.$ air $)$ atmosphere at $37{ }^{\circ} \mathrm{C}$ in regular RPMI 1640 medium supplemented with $10 \mathrm{mmol} / \mathrm{l} \mathrm{HEPES,} \mathrm{10 \%} \mathrm{FCS,} 2 \mathrm{mmol} / \mathrm{l} \mathrm{L}$-glutamine, $1 \mathrm{mmol} / \mathrm{l}$ sodium pyruvate, $50 \mu \mathrm{mol} / \mathrm{l} \beta$-mercaptoethanol (referred to below as complete medium). This clone (832/13) of the INS-1 cell was used because it shows better differentiation characteristics in terms of glucose-stimulated insulin secretion than the original INS-1 cell line [42].

Dispersed human islet cells and INS832/13 cells were plated on poly-ornithine-treated glass coverslips at $80 \%$ confluency in 6-well plates as described before [39]. Following a preincubation in complete medium for $24 \mathrm{~h}$, cells were washed with PBS and incubated for $24 \mathrm{~h}$ at glucose concentrations of 5 or $25 \mathrm{mmol} / \mathrm{l}$ in RPMI containing 1\% FCS (referred to below as incubation medium). Incubation was done in the presence of either $0.5 \% \mathrm{BSA}$ or $0.4 \mathrm{mmol} / 1$ palmitate bound to $0.5 \% \mathrm{BSA}$, with or without $10 \mathrm{nmol} / \mathrm{l} \mathrm{GLP}-1$.

Fluorescence microscopy analysis of cell DNA staining with HOECHST 33342 and with TdT-mediated dUTP nick-end labelling. Apoptosis indexes were assessed by counting Hoechst 33342 (chromatin condensation) and TdT-mediated dUTP-biotin nick-end labelling (TUNEL) (DNA fragmentation) positive cells using a fluorescein in situ cell death detection kit (Roche, Laval, Que, Canada) according to the manufacturer's protocol with few modifications. In brief, cells were fixed in $4 \%$ paraformaldehyde for $1 \mathrm{~h}$, washed with PBS and incubated for $2 \mathrm{~min}$ at room temperature in permeabilisation solution containing $0.1 \%$ Triton X-100 in PBS. Cells were then blocked with $1 \%$ BSA in PBS for $10 \mathrm{~min}$, incubated for $1 \mathrm{~h}$ with TUNEL reaction mixture containing a mouse anti-insulin $(10 \mu \mathrm{g} / \mathrm{ml})$ primary antibody (Sigma, St. Louis, Mo., USA) in order to distinguish beta cells from non-beta cells. After several washes with PBS, cells were stained with a rhodamine-conjugated donkey anti-mouse secondary antibody (Jackson Immunoresearch, West Grove, Calif., USA). Hoechst staining was performed by exposing the slides to $0.5 \mathrm{mg} / \mathrm{ml}$ Hoechst 33342 for $10 \mathrm{~min}$ at room temperature. Slides were then washed several times with PBS and mounted with antifade. The fluorescence of Hoechst, TUNEL and bound anti-insulin antibodies was visualised under a fluorescence microscope at $400 \times$ magnification. At least 200 cells were analysed for each experimental condition. 
DNA fragmentation measurements. Fifty intact human islets of similar size or $80 \%$ confluent INS832/13 cells were seeded and incubated for $24 \mathrm{~h}$ in 6-well plates. DNA fragments were quantified using the Cell Death Detection ELISA Plus Kit (Roche). This kit allows the specific determination of mono- and oligonucleosomes generated by apoptotic cleavage of DNA. After the incubation period, human islets or INS832/13 cells were washed and incubated in a lysis buffer for $30 \mathrm{~min}$ at room temperature according to the manufacturer's protocol. The amount of nucleosomes was quantified photometrically using a FLUOstar Optima microplate reader (BMG Laboratories, Durham, N.C., USA) at $405 \mathrm{~nm}$.

Adenovirus infections. Dominant-negative (DN) PKB and constitutively active PKB [18] overexpression was conducted as described for other adenoviral constructs [39]. INS832/13 cells were seeded 2 days before use in 6-well plates and cultured in regular RPMI as described above. Cells were then infected with different adenoviral constructs (DN-PKB, constitutively active $\mathrm{PKB}$, or green fluorescent protein [GFP] as control) at a multiplicity of infection of $10 \mathrm{pfu} /$ cell for $4 \mathrm{~h}$ in $0.5 \mathrm{ml}$ of complete medium. Complete medium $(1.5 \mathrm{ml})$ was then added to each well and cells were allowed to rest for $20 \mathrm{~h}$ before being incubated under various conditions as described above.

Nuclear extracts and electrophoretic mobility shift assay. Preparation of nuclear extracts and electrophoretic mobility shift assay (EMSA) were performed as described elsewhere [30]. The oligonucleotides used to assess the binding activities of nuclear factor $-\kappa \mathrm{B}(\mathrm{NF}-\kappa \mathrm{B})$ were purchased from ACGT (Toronto, Ont, Canada). A 24-mer oligonucleotide (GCCATGGGGGGATCCCCGAAGTCC) containing an NF- $\kappa \mathrm{B}$ consensus recognition sequence (underlined) was used to measure NF- $\kappa \mathrm{B}$ DNA binding activity. After annealing, the double-stranded oligonucleotides were end-labelled with $\left[\gamma^{32} \mathrm{P}\right]$ ATP (Amersham Biosciences, Montreal, Que, Canada) and $5 \mu \mathrm{g}$ of protein extracts were incubated with a radiolabelled probe $(20,000 \mathrm{cpm}$ per sample). Incubation was done for $20 \mathrm{~min}$ at room temperature in a buffer containing $25 \mathrm{mmol} / \mathrm{l}$ HEPES, $10 \%$ glycerol, $50 \mathrm{mmol} / 1 \mathrm{NaCl}, 0.05 \%$ Nonidet $\mathrm{P}-40$ and $1 \mathrm{mmol} / 1$ dithiothreitol. A 50-fold molar excess of cold oligonucleotide was added with the labelled probe to assess the specificity of nuclear protein binding of the EMSA. Samples were analysed on $4 \%$ non-denaturing polyacrylamide gels containing $0.01 \%$ Nonidet P-40, and relative intensities of shift bands were quantitated by densitometry analysis of the autoradiograms.

RNA isolation and RT-PCR analysis. RT-PCR was performed to semi-quantify mRNA expression of NF- $\mathrm{KB}$-regulated genes. Total RNA was isolated and first strand cDNA synthesised using MMLV reverse transcriptase (Invitrogen, Burlington, Ont, Canada) and hexamers as described previously [44] from INS832/13 cells treated as mentioned above. Complementary DNA preparations were checked for genomic DNA contamination by PCR amplification of the chaperonin matricin, using primers that hybridise to two different exons. Amplification of rat $\beta$-actin, inhibitor of apoptosis protein (IAP)-2 and Bcl-2 were done using Taq polymerase (Invitrogen) and $1.5 \mathrm{mmol} / \mathrm{l}$ $\mathrm{MgCl}_{2}$ in $50 \mu \mathrm{l}$ assay format, and using a PTC-100 thermocycler from MJ Research (Watertown, Mass., USA) set to the following values: $\beta$-actin: $94{ }^{\circ} \mathrm{C}$ for 30 seconds, $63{ }^{\circ} \mathrm{C}$ for 40 seconds, $72{ }^{\circ} \mathrm{C}$ for 40 seconds and 28 cycles; IAP-2 and Bcl-2: $94{ }^{\circ} \mathrm{C}$ for 40 seconds, $52{ }^{\circ} \mathrm{C}$ for 40 seconds, $72{ }^{\circ} \mathrm{C}$ for 40 seconds, and 29 cycles. To ensure that we were working in the linearity of the amplification, the number of cycles used for each gene under study was selected according to a pilot experi- ment performed with cDNAs derived from cells with similar expression levels. The primer sequences and their respective PCR product lengths were as follows: (i) $\beta$-actin, forward $\left(5^{\prime}\right.$ GTGCCCATCTATGAGGGTTACGCG-3'), reverse (5'-GGAACCGCTCATTGCCGATAGTG-3'), fragment (275 bp); (ii) IAP-2, forward (5'-TTGCTTGGAGTACACATACAC-3'), reverse (5'-CAGCTCTACTAAGACTACAG-3'), fragment (382 bp); (iii) Bcl-2, forward (5'-AGATCGTGATGAAGTACATCC-3'), reverse (5'-TAGCGACGAGAGAAGTCATC-3'), fragment (277 bp). After amplification, $5 \mu \mathrm{l}$ of PCR products was subjected to electrophoresis on $1.0 \%$ agarose gels, followed by Southern blotting on Zeta-probe GT membranes (Bio-Rad). A specific oligonucleotide probe for each gene under study was end-labelled with T4 polynucleotide kinase (Amersham) and $\gamma^{32} \mathrm{P}-\mathrm{ATP}$ (Amersham), and used to hybridise the Southern blots. The probes were: $\beta$-actin (5'-TCATGCCATCCTGCGTCTGGACCT-3'); IAP-2 (5'-CTGTCTGTTGACCAGATG-3'); Bcl-2 (5'-AGTGGGATACTGGAGAT-3'). Southern blots were extensively washed and analysed by autoradiography. For each gene studied, only one specific signal at the expected length was detected. Signals were quantified by densitometry analysis of the autoradiograms. IAP-2 and Bcl-2 expression levels were normalised for $\beta$-actin expression.

Preparation of NEFA bound to BSA. This was done as described previously [20].

Calculations and statistics. Data are expressed as means $\pm \mathrm{SE}$ and statistical significance was evaluated by ANOVA, followed by Newman-Keuls post hoc test. A $p$ value of less than 0.05 was considered significant.

\section{Results}

GLP-1 protects human islet cells and INS832/13 cells from gluco-, lipo-, and glucolipotoxicity. To test the possible anti-apoptotic effect of GLP-1 on beta cell glucolipotoxicity, dispersed human islets cells were exposed for a period of $24 \mathrm{~h}$ to 5 or $25 \mathrm{mmol} / \mathrm{l}$ glucose with or without $0.4 \mathrm{mmol} / \mathrm{l}$ palmitate in the presence or absence of GLP-1 (Fig. 1). A concentration of $10 \mathrm{nmol} / \mathrm{l} \mathrm{GLP}-1$ was used throughout this study. It corresponds to a maximal effective concentration that is broadly used in the literature and to plasma concentration of the incretin following a high-carbohydrate meal $[23,30,45,46]$. Figure 1a shows the percentages of apoptotic cells as determined by HOECHST staining in dispersed human islet cells. The use of dispersed islet cells allows the identification of individual beta cells and thus the quantification of apoptosis among the different populations of islet cells. In general, the percentages of apoptotic cells were similar in all populations of cells (beta and non-beta cells). Exposing the cells to $0.4 \mathrm{mmol} / \mathrm{l}$ palmitate increased basal cell death to $30 \%$ (18\% under basal condition). The addition of GLP-1 completely prevented lipotoxicity. The relatively high basal level of apoptosis is similar to that reported by previous studies of isolated intact human islets (9\%) [14] or of islets after dispersion $(22 \%)$ [10]. This might be due in part to: (i) the presence of a low concentration of serum in the incu- 
a

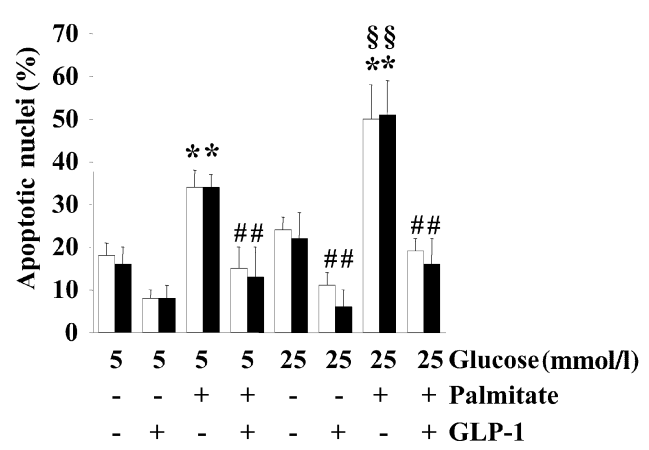

C

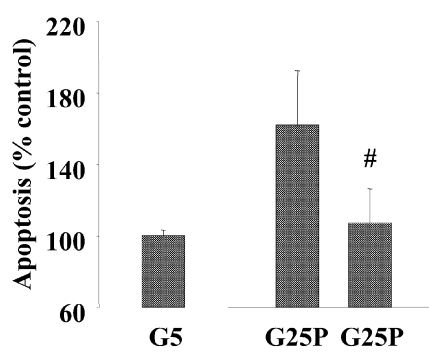

Fig. 1. Glucagon-like peptide-1 prevents gluco-, lipo- and glucolipotoxicity in human pancreatic beta cells and INS832/13 cells. Human islet cells were attached onto coverslips and incubated for $24 \mathrm{~h}$ at 5 or $25 \mathrm{mmol} / \mathrm{l}$ glucose in incubation culture medium (see Materials and methods) with either $0.5 \%$ $\mathrm{BSA}$ or $0.4 \mathrm{mmol} / \mathrm{l}$ palmitate complexed to $0.5 \% \mathrm{BSA}$, in the presence or absence of $10 \mathrm{nmol} / \mathrm{l}$ glucagon-like peptide-1 (GLP-1). Quantification of apoptosis was by HOECHST (a) or TdT-mediated dUTP-biotin nick end-labelling (TUNEL) (b) staining and the beta cell population was identified by insulin immunostaining (see Materials and methods). Representative images of the condition in absence of GLP-1 were shown in a previous paper [20]. a White and black bars denote total islet cells and beta cells respectively. Mean values \pm SE of three separate experiments are shown. At least 200 cells were analysed for each experimental condition. $* p<0.05$ compared to corresponding condition without palmitate; \# $p<0.05$ compared to corresponding condition without GLP- $1 ; \S p<0.05$ compared to $5 \mathrm{mmol} / \mathrm{l}$ glucose with palmitate. b Mean values $\pm \mathrm{SE}$ of

bation medium; (ii) the stress imposed by the dissociation process; and (iii) central necrosis of islets after their isolation. A high glucose concentration ( $25 \mathrm{mmol} / \mathrm{l}$ ) caused a slight but not statistically significant increase in cell death. Again, GLP-1 treatment decreased islet cell apoptosis in the presence of $25 \mathrm{mmol} / \mathrm{l}$ glucose. The combination of high glucose and palmitate concentrations increased cell death to $50 \%$, revealing a synergistic action of the two calorigenic nutrients, in keeping with the glucolipotoxicity concept $[3,20]$. GLP-1 treatment also prevented beta cell glucolipotoxicity, as cell death decreased to $20 \%$.

Figure $1 \mathrm{~b}$ shows the results for the evaluation of apoptosis by TUNEL assay in dispersed human islet cells cultured as described above. The results were
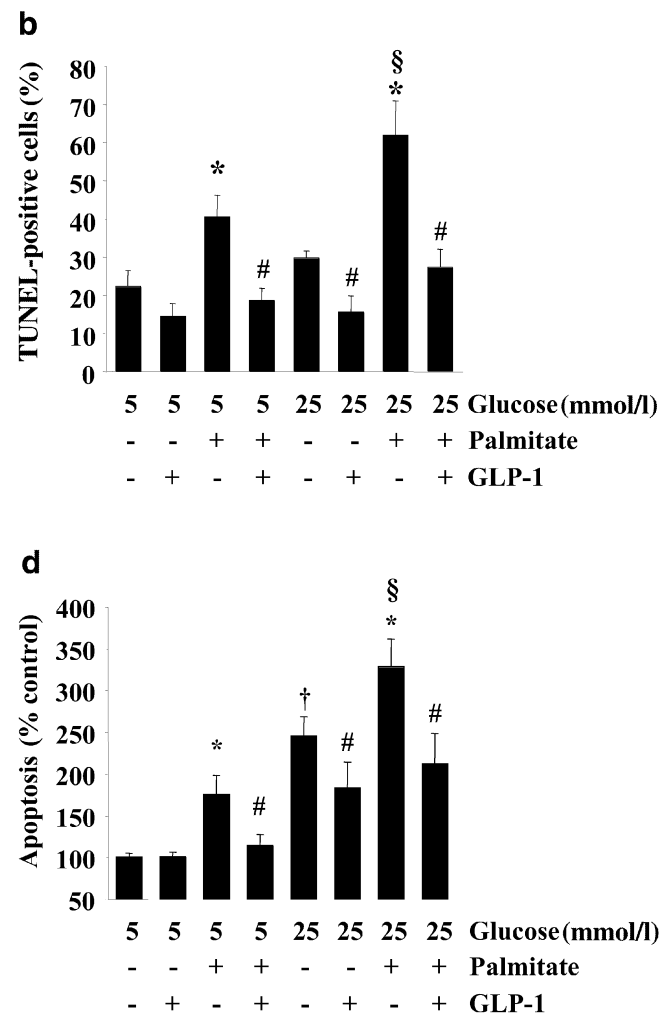

three separate experiments for total islet cells. At least 200 cells were analysed for each experimental condition. $* p<0.05$ compared to corresponding condition without palmitate; \# $p<0.05$ compared to corresponding condition without GLP-1; $\$ p<0.01$ compared to $5 \mathrm{mmol} / \mathrm{l}$ glucose with palmitate. c Intact human islets were treated (see above) and apoptosis was investigated by ELISA (see Materials and methods). G5, $5 \mathrm{mmol} / \mathrm{l}$ glucose; G25P, $25 \mathrm{mmol} / \mathrm{l}$ glucose $+0.4 \mathrm{mmol} / \mathrm{l}$ palmitate. Mean values $\pm \mathrm{SE}$ of three separate experiments are shown. \# $p<0.05$ compared to the corresponding condition without GLP-1. d INS832/13 cells were incubated for $24 \mathrm{~h}$ at $5 \mathrm{mmol} / \mathrm{l}$ or $25 \mathrm{mmol} / \mathrm{l}$ glucose in incubation culture medium with either $0.5 \% \mathrm{BSA}$ or $0.4 \mathrm{mmol} / \mathrm{l}$ palmitate bound to $0.5 \% \mathrm{BSA}$ in the presence or absence of $10 \mathrm{nmol} / 1$ GLP-1. Apoptosis was assessed by ELISA. Values are means \pm SE of three separate experiments. $* p<0.05$ compared to corresponding condition without palmitate; \# $p<0.05$ compared to corresponding condition without GLP-1; $\dagger p<0.001$ compared to $5 \mathrm{mmol} / \mathrm{l}$ glucose; $\S p<0.005$ compared to $5 \mathrm{mmol} / \mathrm{l}$ glucose with palmitate

qualitatively similar to those obtained with HOECHST staining.

The effect of GLP-1 on glucolipotoxicity was also investigated in intact human islets by measuring the fragmentation of DNA using an ELISA assay (Fig. 1c). With respect to the action of GLP-1 on the tested glucolipotoxicity situation, data were similar to those obtained with isolated islet cells (Fig. 1a,b), indicating that GLP-1 prevented glucolipotoxicity in intact human islets.

Due to the limited number of human islets available from each donor and the need for large amounts of biological material to perform most biochemical analyses related to signal transduction, INS832/13 cells were used to gain further insight into the molecu- 


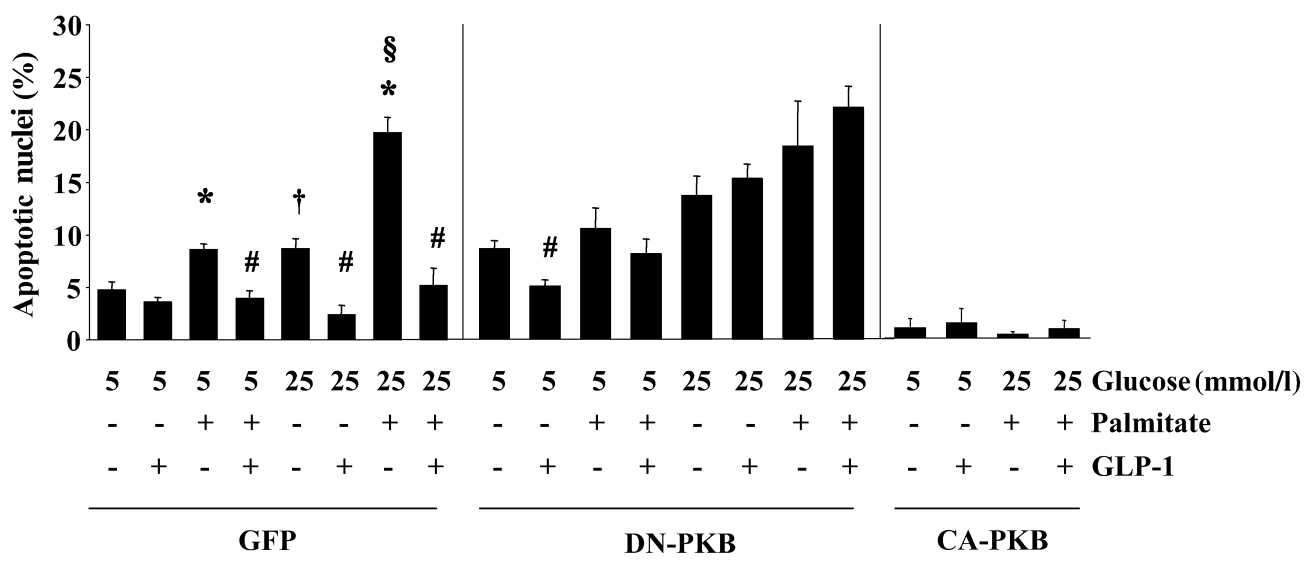

Fig. 2. Adenoviral overexpression of a dominant-negative protein kinase B suppresses the anti-apoptotic action of glucagonlike peptide-1 (GLP-1). INS832/13 cells were infected (see Materials and methods) for overexpression of a dominant-negative and a constitutively active protein kinase B (DN-PKB, CA-PKB) construct or for green fluorescent protein (GFP) as control. After $24 \mathrm{~h}$ infected cells were washed and cultured as described (see legend Fig. 1a) for assessment of dead cells by HOECHST staining. Values are means \pm SE of three separate experiments, in which at least 200 cells were analysed for each experimental condition. * $p<0.001$ compared to the corresponding condition without palmitate; \# $p<0.05$ compared to the corresponding condition without GLP-1; $\dagger p<0.001 \mathrm{com}-$ pared to $5 \mathrm{mmol} / 1$ glucose; $\S p<0.001$ compared to $5 \mathrm{mmol} / \mathrm{l}$ glucose with palmitate

lar mechanism by which GLP-1 exerts its anti-apoptotic effect in connection with toxicity induced by chronic elevated glucose and palmitate concentrations. As with human islet cells, GLP-1 treatment decreased INS832/13 cell apoptosis induced by elevated glucose and palmitate, either on their own or together (Fig. 1d). The results indicate that the INS832/13 cell line is a suitable model for studying the molecular mechanism by which GLP-1 prevents glucolipotoxicity.

The anti-apoptotic action of GLP-1 on beta cell glucolipotoxicity is mediated via the PKB signalling pathway. PKB has been identified as an important component of pro-survival signalling pathways [47] and more relevantly, a constitutively active PKB construct has been shown to prevent lipotoxicity induced by oleate in INS-1 cells [18]. As we and others previously showed that GLP-1 increases PKB activity in beta cells $[39,48]$, we therefore tested a possible implication of PKB in GLP-1's anti-apoptotic action on beta cell glucolipotoxicity. The following values of PKB activity were observed in the absence or presence of GLP-1 (10 nmol/l), following a 15-min incubation period: basal ( $3 \mathrm{mmol} / \mathrm{l}$ glucose): $100 \pm 7 \%$; GLP-1: $176 \pm 37 \% ; p<0.02$ (as evaluated using a $\mathrm{PKB} /$ Akt kinase assay kit [Cell Signaling, Beverly, Mass., USA]). Adenoviral constructs were used to increase the expression level of two PKB mutant pro- teins (DN-PKB and constitutively active $\mathrm{PKB}$ ) in INS832/13 cells before investigating the anti-apoptotic action of GLP-1 by HOECHST staining (Fig. 2). GFP was used as control. We found (Fig. 2) that GLP-1 completely rescued from lipo-, gluco- and glucolipotoxicity control INS832/13 cells infected with an adenovirus encoding for GFP. Overexpressing a DN-PKB slightly increased the basal level of apoptosis but totally counteracted the anti-apoptotic action of GLP-1 on lipo-, gluco- and glucolipotoxicity.

In contrast, the constitutively active PKB construct completely abolished INS832/13 cell apoptosis at $5 \mathrm{mmol} / \mathrm{l}$ glucose, as well as at $25 \mathrm{mmol} / \mathrm{l}$ glucose, in the presence of $0.4 \mathrm{mmol} / \mathrm{l}$ palmitate. The addition of GLP-1 did not decrease apoptosis any further. These data strongly suggest that the anti-apoptotic action of GLP-1 on glucolipotoxicity implicates PKB activation and signalling via its downstream targets.

A role for $N F-\kappa B$ in the anti-apoptotic action of GLP-1. $N F-\kappa B$ is a downstream target of PI-3K/PKB signalling in several systems. The effect of GLP-1 on NF- $\mathrm{KB}$ DNA binding activity was assessed by EMSA (Fig. 3a). The results show that GLP-1 treatment of INS832/13 cells increased NF- $\kappa$ B DNA binding activity by about $80 \%$ after a 2 -h incubation period. This happened at high and low glucose concentrations, with or without palmitate. Neither palmitate nor glucose significantly changed basal and GLP-1-induced NF- $\kappa B$ DNA binding activity. We next investigated the effect of GLP-1 on the expression level of IAP-2 and $B c l-2$, two key anti-apoptotic genes whose expression is under the transcriptional control of NF- $\kappa B$ [49, 50]. Figure $3 b$ shows that GLP- 1 treatment increased the expression level of $I A P-2$ and $B c l-2$, regardless of the glucose concentration and the presence of palmitate.

Finally, to determine whether GLP-1-induced increases in NF- $\kappa \mathrm{B}$ DNA binding activity could account for the anti-apoptotic action of GLP-1, an irreversible pharmacological inhibitor of IkB phosphorylation (BAY 11-7082) was used, which results in the inactivation of NF-kB. As shown in Figure 4, BAY 11-7082 increased the basal level of apoptosis as well as apop- 

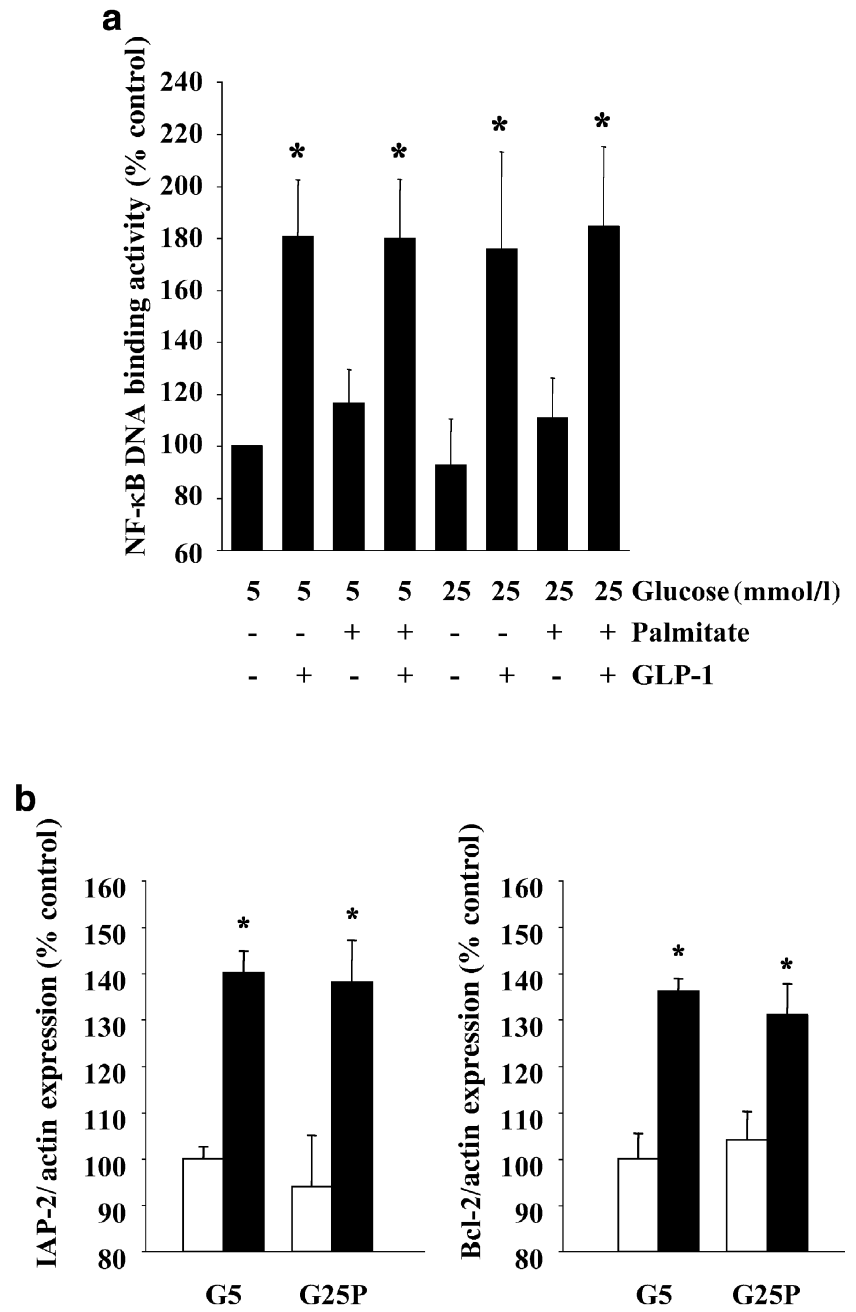

Fig. 3. Glucagon-like peptide-1 increases nuclear factor- $\kappa \mathrm{B}$ $(\mathrm{NF}-\kappa \mathrm{B}) \mathrm{DNA}$ binding activity and the expression of NF- $\mathrm{\kappa B}-$ regulated genes. a DNA retardation assays were performed with nuclear extracts of INS832/13 cells cultured for $2 \mathrm{~h}$ at 5 or $25 \mathrm{mmol} / \mathrm{l}$ glucose in KRB HEPES medium with either $0.4 \mathrm{mmol} / \mathrm{l}$ palmitate complexed to $0.5 \% \mathrm{BSA}$ or with $0.5 \%$ BSA in the presence or absence of $10 \mathrm{nmol} / \mathrm{l}$ glucagon-like peptide-1 (GLP-1). A probe containing a consensus NF- $\kappa \mathrm{B}-\mathrm{re}-$ sponsive element was used to assess NF- $\kappa$ B DNA binding activity. Quantification of DNA retardation is shown. Data are means $\pm \mathrm{SE}$ of four experiments. $* p<0.05$ compared to the corresponding condition without GLP-1. b GLP-1 increases the expression level of inhibitor of apoptosis protein (IAP-2) and Bcl-2. INS 832/13 cells were incubated for $6 \mathrm{~h}$ (see legend Fig. 1d) in the absence $(\square)$ or presence $(\square)$ of $10 \mathrm{nmol} / \mathrm{l} \mathrm{GLP}$ 1. RNA was then extracted and the expression of IAP-2 and Bcl-2 was analysed by RT-PCR. G5, $5 \mathrm{mmol} / \mathrm{l}$ glucose; G25P, $25 \mathrm{mmol} / \mathrm{l}$ glucose $+0.4 \mathrm{mmol} / \mathrm{l}$ palmitate. Values are means \pm $\mathrm{SE}$ of three separate experiments. $* p<0.05$ compared to the corresponding condition without GLP-1

tosis induced by the combined presence of elevated glucose and palmitate. Such potentiation of stimuliinduced apoptosis with inhibition of NF- $\mathrm{KB}$ has been previously reported in other cell systems $[51,52,53$, 54]. This result suggests that the inhibition of NF- $\kappa B$ by the pharmacological inhibitor BAY 11-7082 may

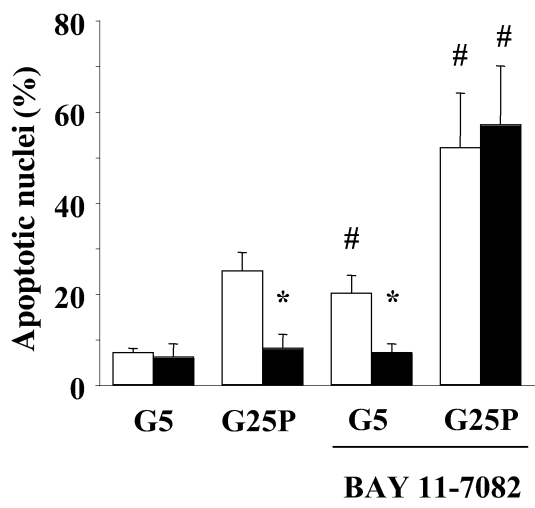

Fig. 4. Nuclear factor- $\kappa B$ inhibition suppresses the anti-apoptotic action of glucagon-like peptide-1 (GLP-1) on glucolipotoxicity. INS832/13 cells were cultured for $24 \mathrm{~h}$ at $5 \mathrm{mmol} / \mathrm{l}$ glucose or $25 \mathrm{mmol} / \mathrm{l}$ glucose, with or without $0.4 \mathrm{mmol} / \mathrm{l}$ palmitate complexed to $0.5 \% \mathrm{BSA}$ or with $0.5 \% \mathrm{BSA}$, in the absence $(\square)$ or presence $(\square)$ of $10 \mathrm{nmol} / \mathrm{l} \mathrm{GLP}-1$ and $20 \mu \mathrm{mol} / \mathrm{l}$ BAY 11-7082. Apoptosis was quantified by HOECHST staining. Values are means \pm SE of three separate experiments in which at least 200 cells were analysed for each experimental condition. * $p<0.05$ compared to the corresponding condition without GLP-1; \# $p<0.05$ compared to the corresponding condition without BAY 11-7082. G5, $5 \mathrm{mmol} / \mathrm{l}$ glucose; G25P, $25 \mathrm{mmol} / \mathrm{l}$ glucose $+0.4 \mathrm{mmol} / \mathrm{l}$ palmitate

sensitise cells to potential injuries. The presence of BAY 11-7082 totally abolished the preventive effect of GLP-1 on glucolipotoxicity. Similar observations were made when INS832/13 cells were treated with high glucose or palmitate concentrations alone, where the addition of BAY 11-7082 suppressed GLP-1's anti-apoptotic effect in two separate experiments (data not shown).

\section{Discussion}

Using complementary pharmacological, biochemical and molecular biology approaches, we provide evidence that GLP-1, a gluco-incretin hormone under consideration for diabetes treatment [25, 26], prevents glucose- and palmitate-induced apoptosis in the beta cell by a mechanism involving PKB and its downstream target NF- $\mathrm{BB}$.

Recent studies have investigated the effect of chronic elevated glucose and NEFA concentrations on beta cell function [4]. Long-term exposure of the beta cell to high glucose induces glucose desensitisation, depletion of the readily releasable pool of insulin and may cause apoptosis [55]. Long-term exposure of beta cells to NEFA increases basal insulin release but inhibits glucose-induced insulin secretion [56]. NEFA also reduces glucose-induced insulin gene expression [57] and induces beta cell apoptosis [58]. According to the glucolipotoxicity concept proposed by us, glucose and fatty acids synergise in causing beta cell malfunction, due to the fact that high glucose inhibits 
fat oxidation and consequently lipid detoxification [1, $2]$. The present study shows that GLP-1 prevents beta cell gluco-, lipo- and glucolipotoxicity in human islets as well as in INS832/13 cells.

Recent studies by our group and others have shown that GLP-1, via transactivation of the EGF receptor, activates the PI-3K/PKB signalling pathway [30, 39, $40,48]$, a cascade of signal transduction that prevents apoptosis in several systems. Therefore, we aimed at investigating the implication of PKB in GLP-1 antiapoptotic action. The overexpression of a dominant-negative PKB construct in INS832/13 cells suppressed the anti-apoptotic action of GLP-1 on gluco-, lipo- and glucolipotoxicity. Overexpressing a constitutively active form of PKB abolished the cytotoxic effect of glucose and palmitate. This supports the view that GLP-1 prevents glucolipotoxicity, at least in part, via the activation of PKB and its downstream targets. Consistently with this result, PKB has been shown to play an important role in the regulation of beta cell mass. Indeed, two recent studies have demonstrated that transgenic mice expressing a constitutively active form of PKB had significantly greater beta cell mass than control animals [59, 60]. Moreover, these transgenic mice were protected from streptozotocininduced diabetes. Both of these studies reported increased beta cell neogenesis and at least one of them an increase in beta cell proliferation [59]. The present study, with a previous one [18], shows that PKB plays an important role in the prevention of beta cell apoptosis. Therefore we suggest that PKB could play a key role in the regulation of beta cell mass via a complex mechanism that not only implies neogenesis and beta cell replication, but in addition the prevention of apoptosis.

We also examined the effects of GLP-1 on NF- $\kappa B$, a downstream target of PKB that plays a role in the control of apoptosis. The NF- $\kappa \mathrm{B}$ family of transcription factors is comprised of several proteins that act as homo- and heterodimers. In vertebrates, this family includes p50, p52, Rel-A (also known as p65), c-Rel and Rel-B. In most cells, NF- $\kappa \mathrm{B}$ complexes are present in the cytoplasm in their latent form, bound to the inhibitor IkB. PKB can rapidly phosphorylate IkB to induce its ubiquitination and degradation by the $26 \mathrm{~S}$ proteasome, releasing the active form of NF- $\mathrm{KB}$. Interestingly, IkB is also a potential target for $\mathrm{PKC}-\zeta$ [61], which is activated by GLP-1 [39]. Upon its activation, NF- $\kappa \mathrm{B}$ will translocate to the nucleus to promote expression of stress-inducible genes that can be either pro- or anti-apoptotic, depending on cell system and stimuli [62, 63, 64, 65]. For instance, NF- $\mathrm{KB}$ binding sites have been found in the promoter regions of pro-apoptotic genes like inducible nitric oxide synthase [66], cytokines [67], fas and fas-ligand [68]. Examples of anti-apoptotic proteins whose expression is increased by NF- $\mathrm{KB}$ are: caspase inhibitors IAP-1, IAP-2 and XIAP [49], mitochondria membrane sta- bilisers such as Bcl-2 [50], Bcl-xl and Bfl-1 [69], and cell-cycle regulatory proteins like cyclin D1 [70, 71]. The selectivity of the transcriptional response to $\mathrm{NF}-\kappa \mathrm{B}$ will depend in part on the combinatorial response with other signalling pathway and/or transcription factors [64]. Previous studies have demonstrated a pro-apoptotic role of NF- $\kappa \mathrm{B}$ in human islets in response to cytokines $[8,72]$. Our present study shows that GLP-1 activates NF- $\kappa$ B independently of the glucose concentration or the presence of palmitate. Also, a pharmacological inhibitor of NF- $\kappa B$ suppressed GLP-1 anti-apoptotic action and sensitised INS832/13 cells to subsequent stress (glucolipotoxicity). Such potentiation of stimuli-induced apoptosis by inhibition of $\mathrm{NF}-\kappa \mathrm{B}$ has been previously reported in various cell systems. Indeed, similar observations were made with the expression of a super-repressor form of IkB [51, $53,54]$ and the use of a pharmacological inhibitor as well as an inhibitory double-stranded oligonucleotide decoy for NF- $\kappa B$ [52], all of which increased percentages of cell death in response to a variety of stimuli. In our study, we envision that the suppression of either PKB (by DN-PKB in Fig. 2) or NF- $\mathrm{BB}$ activity (by BAY 11-7082 in Fig. 4) sensitises cells to apoptosis in a context of low serum concentration, thus resulting in a slightly increased basal level of apoptosis. However, it is difficult to explain why GLP-1 treatment prevents this rise in apoptosis under basal conditions and not under conditions of glucolipotoxicity. Conceivably, a signalling factor such as cyclic AMP, which is known to be induced by GLP-1 in a PKB/NF- $\mathrm{KB}$-independent manner, could mediate an anti-apoptotic action of GLP-1 under a relatively low stress condition (5 mmol/l glucose) [73]. However, the anti-apoptotic action of cyclic AMP signalling could be inefficient under the high stress of glucolipotoxicity. Under such a condition, only PI-3K/NF- $\kappa \mathrm{B}$ signalling would be able to reduce the major stress of glucolipotoxicity. Thus, the data presented here suggest that NF- $\kappa \mathrm{B}$ is necessary for a GLP-1 anti-apoptotic response in INS832/13 cells upon treatment with high glucose and NEFA concentrations. To identify the target genes of GLP-1-induced NF- $\kappa B$ DNA binding activity, we investigated the effect of GLP-1 on IAP-2 and $\mathrm{Bcl}-2$ gene expression. GLP-1 treatment increased the expression level of both potential NF-KB targets IAP-2 and $B c l-2$. Although, additional work is required to conclusively define the exact role of NF- $\kappa \mathrm{B}$ in protecting against glucolipotoxicity, the data presented here suggest that GLP-1 prevents beta cell glucolipotoxicity via activation of NF- $\kappa \mathrm{B}$ DNA binding activity, which would lead to an increase in IAP-2 and $\mathrm{Bcl}-2$ gene expression.

In the current study, we suggest that the activation of NF- $\mathrm{KB}$ after GLP-1 action on the beta cell is linked to an anti-apoptosis action of the transcriptional factor. This contrasts with several studies, in particular studies involving cytokines, where NF- $\mathrm{\kappa B}$ activation 
was associated with a pro-apoptosis action [8]. However, depending on the cell type and experimental system, NF- $\mathrm{BB}$ activation has been linked to protective [74] and pro-apoptotic actions [72].

In conclusion, our data demonstrate that GLP-1 prevents glucose- and palmitate-induced apoptosis, singly or combined, in human islet cells, as well as in INS832/13 cells. The mechanisms involved could imply $\mathrm{PKB}$ activation, enhanced NF- $\mathrm{KB}$ DNA binding activity, and possibly increased $I A P-2$ and $B c l-2$ gene expression. The anti-apoptotic action of GLP-1, added to its incretin effect, increases interest in its utilisation as a therapeutic agent in the treatment of Type 2 diabetes, since GLP-1 could prevent beta cell apoptosis due to glucolipotoxicity, which is thought to be responsible for beta cell decompensation in the development of obesity-associated Type 2 diabetes.

Acknowledgements. This work was supported by the Juvenile Diabetes Research Foundation Diabetes Center at McGill University and the University of Montreal, and by grants from the Canadian Institute of Health Research and the Canadian Diabetes Association (to M. Prentki). J. Buteau was supported by a Canadian Institutes of Health Research Studentship.

\section{References}

1. Prentki M (1996) New insights into pancreatic beta-cell metabolic signaling in insulin secretion. Eur J Endocrinol 134:272-286

2. Prentki M, Corkey BE (1996) Are the beta-cell signaling molecules malonyl-CoA and cystolic long-chain acyl-CoA implicated in multiple tissue defects of obesity and NIDDM? Diabetes 45:273-283

3. Prentki M, Joly E, El-Assaad W, Roduit R (2002) MalonylCoA signaling, lipid partitioning, and glucolipotoxicity: role in beta-cell adaptation and failure in the etiology of diabetes. Diabetes 51 [Suppl 3]:S405-S413

4. Poitout V, Robertson RP (2002) Secondary beta-cell failure in type 2 diabetes - a convergence of glucotoxicity and lipotoxicity. Endocrinology 143:339-342

5. Alarcon C, Wicksteed B, Prentki M, Corkey BE, Rhodes CJ (2002) Succinate is a preferential metabolic stimuluscoupling signal for glucose-induced proinsulin biosynthesis translation. Diabetes 51:2496-2504

6. Marshak S, Leibowitz G, Bertuzzi F et al. (1999) Impaired beta-cell functions induced by chronic exposure of cultured human pancreatic islets to high glucose. Diabetes 48: 1230-1236

7. Donath MY, Gross DJ, Cerasi E, Kaiser N (1999) Hyperglycemia-induced beta-cell apoptosis in pancreatic islets of Psammomys obesus during development of diabetes. Diabetes 48:738-744

8. Maedler K, Sergeev P, Ris F et al. (2002) Glucose-induced beta cell production of IL-1beta contributes to glucotoxicity in human pancreatic islets. J Clin Invest 110:851-860

9. Efanova IB, Zaitsev SV, Zhivotovsky B et al. (1998) Glucose and tolbutamide induce apoptosis in pancreatic betacells. A process dependent on intracellular $\mathrm{Ca} 2+$ concentration. J Biol Chem 273:33501-33507

10. Federici M, Hribal M, Perego L et al. (2001) High glucose causes apoptosis in cultured human pancreatic islets of
Langerhans: a potential role for regulation of specific $\mathrm{Bcl}$ family genes toward an apoptotic cell death program. Diabetes 50:1290-1301

11. Laybutt DR, Weir GC, Kaneto H et al. (2002) Overexpression of c-Myc in beta-cells of transgenic mice causes proliferation and apoptosis, downregulation of insulin gene expression, and diabetes. Diabetes 51:1793-1804

12. Warnotte C, Gilon P, Nenquin M, Henquin JC (1994) Mechanisms of the stimulation of insulin release by saturated fatty acids. A study of palmitate effects in mouse beta-cells. Diabetes 43:703-711

13. Maestre I, Jordan J, Calvo S et al. (2003) Mitochondrial dysfunction is involved in apoptosis induced by serum withdrawal and fatty acids in the beta-cell line INS-1. Endocrinology 144:335-345

14. Lupi R, Dotta F, Marselli L et al. (2002) Prolonged exposure to free fatty acids has cytostatic and pro-apoptotic effects on human pancreatic islets: evidence that beta-cell death is caspase-mediated, partially dependent on ceramide pathway, and Bcl-2-regulated. Diabetes 51:1437-1442

15. Shimabukuro M, Zhou YT, Levi M, Unger RH (1998) Fatty acid-induced beta cell apoptosis: a link between obesity and diabetes. Proc Natl Acad Sci USA 95:2498-2502

16. Briaud I, Harmon JS, Kelpe CL, Segu VB, Poitout V (2001) Lipotoxicity of the pancreatic beta-cell is associated with glucose-dependent esterification of fatty acids into neutral lipids. Diabetes 50:315-321

17. Maedler K, Spinas GA, Dyntar D, Moritz W, Kaiser N, Donath MY (2001) Distinct effects of saturated and monounsaturated fatty acids on beta-cell turnover and function. Diabetes 50:69-76

18. Wrede CE, Dickson LM, Lingohr MK, Briaud I, Rhodes CJ (2002) Protein kinase B/Akt prevents fatty acid-induced apoptosis in pancreatic beta-cells (INS-1). J Biol Chem 277:49676-49684

19. Prentki M, Roduit R, Lameloise N, Corkey BE, Assimacopoulos-Jeannet F (2001) Glucolipotoxicity, lipotoxicity and pancreatic beta cell failure: a role for malonylCoA, PPAR alpha and altered lipid partitioning? Can J Diab Care 25:36-46

20. El-Assaad W, Buteau J, Peyot ML et al. (2003) Saturated fatty acids synergize with elevated glucose to cause pancreatic beta-cell death. Endocrinology 144:4154-4163

21. Fehmann HC, Goke R, Goke B (1995) Cell and molecular biology of the incretin hormones glucagon-like peptide-I and glucose-dependent insulin releasing polypeptide. Endocr Rev 16:390-410

22. Holz GG, Kuhtreiber WM, Habener JF (1993) Pancreatic beta-cells are rendered glucose-competent by the insulinotropic hormone glucagon-like peptide-1(7-37). Nature 361:362-365

23. Thorens B, Waeber G (1993) Glucagon-like peptide-I and the control of insulin secretion in the normal state and in NIDDM. Diabetes 42:1219-1225

24. Drucker DJ (2001) Minireview: the glucagon-like peptides. Endocrinology 142:521-527

25. Gutniak M, Orskov C, Holst JJ, Ahren B, Efendic S (1992) Antidiabetogenic effect of glucagon-like peptide-1 (7-36) amide in normal subjects and patients with diabetes mellitus. N Engl J Med 326:1316-1322

26. Holst JJ (2002) Therapy of type 2 diabetes mellitus based on the actions of glucagon-like peptide-1. Diabetes Metab Res Rev 18:430-441

27. Fehmann HC, Habener JF (1992) Insulinotropic hormone glucagon-like peptide-I(7-37) stimulation of proinsulin gene expression and proinsulin biosynthesis in insulinoma beta TC-1 cells. Endocrinology 130:159-166 
28. Susini S, Roche E, Prentki M, Schlegel W (1998) Glucose and glucoincretin peptides synergize to induce c-fos, c-jun, junB, zif-268, and nur-77 gene expression in pancreatic beta (INS-1) cells. Faseb J 12:1173-1182

29. Susini S, van Haasteren G, Li S, Prentki M, Schlegel W (2000) Essentiality of intron control in the induction of c-fos by glucose and glucoincretin peptides in INS-1 betacells. Faseb J 14:128-136

30. Buteau J, Roduit R, Susini S, Prentki M (1999) Glucagonlike peptide-1 promotes DNA synthesis, activates phosphatidylinositol 3-kinase and increases transcription factor pancreatic and duodenal homeobox gene 1 (PDX-1) DNA binding activity in beta (INS-1)-cells. Diabetologia 42: 856-864

31. Stoffers DA, Kieffer TJ, Hussain MA et al. (2000) Insulinotropic glucagon-like peptide 1 agonists stimulate expression of homeodomain protein IDX-1 and increase islet size in mouse pancreas. Diabetes 49:741-748

32. Jonsson J, Carlsson L, Edlund T, Edlund H (1994) Insulinpromoter-factor 1 is required for pancreas development in mice. Nature 371:606-609

33. Oster A, Jensen J, Serup P, Galante P, Madsen OD, Larsson LI (1998) Rat endocrine pancreatic development in relation to two homeobox gene products (Pdx-1 and $\mathrm{Nkx}$ 6.1). J Histochem Cytochem 46:707-715

34. Waeber G, Thompson N, Nicod P, Bonny C (1996) Transcriptional activation of the GLUT2 gene by the IPF1/STF-1/IDX-1 homeobox factor. Mol Endocrinol 10: 1327-1334

35. Holz GG, Leech CA, Heller RS, Castonguay M, Habener JF (1999) cAMP-dependent mobilization of intracellular $\mathrm{Ca}^{2+}$ stores by activation of ryanodine receptors in pancreatic beta-cells. $\mathrm{A} \mathrm{Ca}^{2+}$ signaling system stimulated by the insulinotropic hormone glucagon-like peptide-1-(7-37). J Biol Chem 274:14147-14156

36. Tsuboi T, Silva Xavier G da, Holz GG, Jouaville LS, Thomas AP, Rutter GA (2003) Glucagon-like peptide-1 mobilizes intracellular $\mathrm{Ca}^{2+}$ and stimulates mitochondrial ATP synthesis in pancreatic MIN6 beta-cells. Biochem J 369:287-299

37. Kang G, Chepurny OG, Holz GG (2001) cAMP-regulated guanine nucleotide exchange factor II (Epac2) mediates $\mathrm{Ca}^{2+}$-induced $\mathrm{Ca}^{2+}$ release in INS-1 pancreatic beta-cells. J Physiol 536:375-385

38. Farilla L, Hui H, Bertolotto C et al. (2002) Glucagon-like peptide-1 promotes islet cell growth and inhibits apoptosis in Zucker diabetic rats. Endocrinology 143:4397-4408

39. Buteau J, Foisy S, Rhodes CJ, Carpenter L, Biden TJ, Prentki M (2001) Protein kinase C zeta activation mediates glucagon-like peptide-1-induced pancreatic beta-cell proliferation. Diabetes 50:2237-2243

40. Buteau J, Foisy S, Joly E, Prentki M (2003) Glucagon-like peptide 1 induces pancreatic beta-cell proliferation via transactivation of the epidermal growth factor receptor. Diabetes 52:124-132

41. Li Y, Hansotia T, Yusta B, Ris F, Halban PA, Drucker DJ (2003) Glucagon-like peptide-1 receptor signaling modulates beta cell apoptosis. J Biol Chem 278:471-478

42. Hohmeier HE, Mulder H, Chen G, Henkel-Rieger R, Prentki M, Newgard CB (2000) Isolation of INS-1-derived cell lines with robust ATP-sensitive $\mathrm{K}^{+}$channel-dependent and -independent glucose-stimulated insulin secretion. Diabetes 49:424-430

43. Asfari M, Janjic D, Meda P, Li G, Halban PA, Wollheim CB (1992) Establishment of 2-mercaptoethanol-dependent differentiated insulin-secreting cell lines. Endocrinology 130:167-178
44. Roduit R, Morin J, Masse F et al. (2000) Glucose downregulates the expression of the peroxisome proliferatoractivated receptor-alpha gene in the pancreatic beta-cell. J Biol Chem 275:35799-35806

45. Thorens B (1992) Expression cloning of the pancreatic beta cell receptor for the gluco-incretin hormone glucagon-like peptide 1. Proc Natl Acad Sci USA 89:8641-8645

46. Drucker DJ (2003) Glucagon-like peptides: regulators of cell proliferation, differentiation, and apoptosis. Mol Endocrinol 17:161-171

47. Cross TG, Scheel-Toellner D, Henriquez NV, Deacon E, Salmon M, Lord JM (2000) Serine/threonine protein kinases and apoptosis. Exp Cell Res 256:34-41

48. Trumper K, Trumper A, Trusheim H, Arnold R, Goke B, Horsch D (2000) Integrative mitogenic role of protein kinase B/Akt in beta-cells. Ann NY Acad Sci 921:242-250

49. Wang CY, Mayo MW, Korneluk RG, Goeddel DV, Baldwin AS Jr (1998) NF-kappaB anti-apoptosis: induction of TRAF1 and TRAF2 and c-IAP1 and c-IAP2 to suppress caspase-8 activation. Science 281:1680-1683

50. Mattson MP, Camandola S (2001) NF-kappaB in neuronal plasticity and neurodegenerative disorders. J Clin Invest 107:247-254

51. Antwerp DJ van, Martin SJ, Kafri T, Green DR, Verma IM (1996) Suppression of TNF-alpha-induced apoptosis by NF-kappa B. Science 274:787-789

52. Sumitomo M, Tachibana M, Nakashima J et al. (1999) An essential role for nuclear factor kappa B in preventing TNF-alpha-induced cell death in prostate cancer cells. J Urol 161:674-679

53. Wang CY, Mayo MW, Baldwin AS Jr (1996) TNF- and cancer therapy-induced apoptosis: potentiation by inhibition of NF-kappa B. Science 274:784-787

54. Muenchen HJ, Lin DL, Walsh MA, Keller ET, Pienta KJ (2000) Tumor necrosis factor-alpha-induced apoptosis in prostate cancer cells through inhibition of nuclear factorkappa B by an IkappaBalpha "super-repressor". Clin Cancer Res 6:1969-1977

55. Poitout V, Robertson RP (1996) An integrated view of beta-cell dysfunction in type-II diabetes. Annu Rev Med 47:69-83

56. Segall L, Lameloise N, Assimacopoulos-Jeannet F et al. (1999) Lipid rather than glucose metabolism is implicated in altered insulin secretion caused by oleate in INS-1 cells. Am J Physiol 277:E521-E528

57. Gremlich S, Bonny C, Waeber G, Thorens B (1997) Fatty acids decrease IDX-1 expression in rat pancreatic islets and reduce GLUT2, glucokinase, insulin, and somatostatin levels. J Biol Chem 272:30261-30269

58. Unger RH (1995) Lipotoxicity in the pathogenesis of obesity-dependent NIDDM. Genetic and clinical implications. Diabetes 44:863-870

59. Bernal-Mizrachi E, Wen W, Stahlhut S, Welling CM, Permutt MA (2001) Islet beta cell expression of constitutively active Akt1/PKB alpha induces striking hypertrophy, hyperplasia, and hyperinsulinemia. J Clin Invest 108: 1631-1638

60. Tuttle RL, Gill NS, Pugh W et al. (2001) Regulation of pancreatic beta-cell growth and survival by the serine/threonine protein kinase Akt1/PKBalpha. Nat Med 7:1133-1137

61. Diaz-Meco MT, Berra E, Municio MM et al. (1993) A dominant negative protein kinase $\mathrm{C}$ zeta subspecies blocks NF-kappa B activation. Mol Cell Biol 13:4770-4775

62. Baldwin AS (2001) Control of oncogenesis and cancer therapy resistance by the transcription factor NF-kappa B. J Clin Invest 107:241-246 
63. Barkett M, Gilmore TD (1999) Control of apoptosis by Rel/NF-kappa B transcription factors. Oncogene 18: 69106924

64. Pahl HL (1999) Activators and target genes of Rel/ NF-kappa B transcription factors. Oncogene 18:6853-6866

65. Chen F, Castranova V, Shi X (2001) New insights into the role of nuclear factor-kappa B in cell growth regulation. Am J Pathol 159:387-397

66. Taylor BS, Vera ME de, Ganster RW et al. (1998) Multiple NF-kappa B enhancer elements regulate cytokine induction of the human inducible nitric oxide synthase gene. J Biol Chem 273:15148-15156

67. Hiscott J, Marois J, Garoufalis J et al. (1993) Characterization of a functional NF-kappa B site in the human interleukin 1 beta promoter: evidence for a positive autoregulatory loop. Mol Cell Biol 13:6231-6240

68. Matsui K, Fine A, Zhu B, Marshak-Rothstein A, Ju ST (1998) Identification of two NF-kappa B sites in mouse CD95 ligand (Fas ligand) promoter: functional analysis in T cell hybridoma. J Immunol 161:3469-3473

69. Lee HH, Dadgostar H, Cheng Q, Shu J, Cheng G (1999) NF-kappa B-mediated up-regulation of Bcl-x and Bfl-1/A1 is required for CD40 survival signaling in B lymphocytes. Proc Natl Acad Sci USA 96:9136-9141

70. Hinz M, Krappmann D, Eichten A, Heder A, Scheidereit C, Strauss M (1999) NF-kappa B function in growth control: regulation of cyclin D1 expression and G0/G1-to-S-phase transition. Mol Cell Biol 19:2690-2698

71. Guttridge DC, Albanese C, Reuther JY, Pestell RG, Baldwin AS Jr (1999) NF-kappa B controls cell growth and differentiation through transcriptional regulation of cyclin D1. Mol Cell Biol 19:5785-5799

72. Giannoukakis N, Rudert WA, Trucco M, Robbins PD (2000) Protection of human islets from the effects of interleukin-1 beta by adenoviral gene transfer of an Ikappa B repressor. J Biol Chem 275:36509-36513

73. Hui H, Nourparvar A, Zhao X, Perfetti R (2003) Glucagonlike peptide-1 inhibits apoptosis of insulin-secreting cells via a cyclic 5'-adenosine monophosphate-dependent protein kinase A- and a phosphatidylinositol 3-kinasedependent pathway. Endocrinology 144:1444-1455

74. Chang I, Kim S, Kim JY et al. (2003) Nuclear factor kappa B protects pancreatic beta cells from tumor necrosis factoralpha-mediated apoptosis. Diabetes 52:1169-1175 